\title{
AN ANALYSIS OF LEAKAGE AND INJECTION OF HOUSEHOLDS RELATED TO SOCIO-ECONOMIC OPPORTUNITIES AND MOBILITY IN SELECTED DISTRICTS OF CENTRAL PUNJAB, PAKISTAN
}

\author{
Samra Kahlid ${ }^{1}$, Nabila Asghar ${ }^{2}$, Hafeez ur Rehman ${ }^{3 *}$
}

${ }^{1}$ Assistant Professor, Higher Education Department, Government of the Punjab Lahore, Pakistan; ${ }^{2}$ Associate Professor, Department of Economics and Business Administration, Division of Arts and Social Sciences University of Education Lahore, Pakistan; ${ }^{3 *}$ Professor/Chairman, Department of Economics-SBE, University of Management and Technology Lahore, Pakistan.

Email: ${ }^{1}$ samrakhalid88@yahoo.com, ${ }^{2}$ nabeela.asghar@ue.edu.pk, ${ }^{3 *}$ hafeez.rehman@umt.edu.pk Article History: Received on $26^{\text {th }}$ March 2021, Revised on $20^{\text {th }}$ April 2021, Published on $2^{\text {nd }}$ May 2021

\begin{abstract}
Purpose of the study: This study deals with leakages and injections of households due to socio-economic opportunities and mobility in Central Punjab, Pakistan. During the past few decades, researchers have been trying to analyze the changes caused by mobility in the socio-economic stratification of society over time.
\end{abstract}

Methodology: For analysis purposes, the study uses primary data collected from the three selected districts of Central Punjab. The study used Principal Component Analysis (PCA) for calculating the Socio-economic Status Index (SESI) by assigning the weights to indicators. The sample size is taken from 370 respondents by interviews. The sample size has been determined based on the population of each district, such as rural and urban.

Main Findings: The results show that both creeper and struggling strata experience low mobility because households consider their basic needs highly important. The size of both low strata decreases due to leakages of households; while, the size of other strata increases due to the injection of households from low strata. The logistic regression results show the substantial contribution of both education and occupation in improving the socio-economic status of the households.

Applications of this study: This study can provide guidelines to the policymakers for formulating appropriate policies that are relatively flexible for the middle stratum compared to creeper and ruler strata in Central Punjab.

Novelty/Originality of this study: The novelty of the study is that it brings up the true picture of the structure of Central Punjab through estimating the household transformation by using leakage and injection in terms of intra-generational and intra-temporal household mobility. The results of the study can be used to reduce the income inequality in Central Punjab.

Keywords: Socio-economic Factors, Stratification, Socio-economic Mobility, Leakage and Injection.

\section{INTRODUCTION}

Socio-economic mobility is related to the structural modification in agriculture, industry, and services sectors characterized by quantitative changes in output and employment (Weissberger et al., 2021). In a society, mobility is linked with positive socio-economic changes, making the people enjoy a high quality of life index based on improved education infrastructural reforms (Cepeliauskaite et al., 2021). The researchers have developed a socio-economic status scale with more socio-economic variables such as housing, material possession, education, occupation, income, land, and social participation. Tiwari and Kumar (2005) have made a clear distinction between socio-economic stratification and socio-economic mobility as stratification measures the household socio-economic position of households at the current point time; whereas, socio-economic mobility measures the household's socio-economic position between two distinct periods (Grusky, 2001). With the development of society, it becomes significant to calculate the class hierarchy because it investigates whether we live in an open or closed society. In a closed society, households have no access to education and labour market opportunities (Wuyts \& Kilama, 2014). As a result, they have low chances to move upward in the hierarchy system. It has become important for emerging and developing societies to measure the class structure and extent of mobility that happened in the last couple of decades.

The researchers have identified several factors that cause changes in households' socio-economic status (Jimoh et al., 2021). Some factors encourage households of lower social class to pursue a high level of education and have proper access to the occupation market, which provide them better jobs and career prospects (Connor \& Dewson, 2001; Miliband, 2003; Machin, 2004). On the other hand, some factors have been identified as barriers to lower socioeconomic groups. These factors include financial, physical, and geographical hurdles and lack of encouragement to pursue higher education. Since the beginning of the present century, most of the studies have identified several socioeconomic factors related to the mobility of households, such as education, occupation, and income but fail to bring up a clear picture related to the structural changes in society (Salata \& Scalon, 2020).

The previous studies on this subject matter have shown the different points of view regarding economic opportunities and mobility. For example, Delorenzi (2006) thinks that geographical mobility provides sufficient chances to educated youth to improve their socio-economic conditions. Corak (2013) points out that the major cause of inter-generational 
mobility in the US is the high earning of parents who influence policies to benefit their future generations. Goldthorpe (2016) describes that education is the best positional good and motivational factor for the households to move up in the upper strata. Khalid and Asghar (2018) think that an improvement in the education of the head of households, geographical movement, and occupation progression contributes to the intra-temporal and intragenerational mobility in Central Punjab, Pakistan. In another study, Khalid and Asghar (2019) point out that the degree of socio-economic mobility is positively linked with life chances in Southern Punjab, Pakistan. These studies ignore the analysis based on leakage and injection of households with emphasis on economic opportunities and mobility in developing societies. Furthermore, these studies do not analyze the impact of changes on the economic position of households over time in the context of socio-economic distribution and mobility in different domains (Ritchie et al., 2005).

The present study may be the comprehensive benchmark to establish the broad type of criteria in mobility. Most of the studies have used the idea of Okun (2015), which describes how many households leak and inject from the particular strata and how much strata size increases or decreases due to mobility over time. The high mobility from lower strata toward higher strata means the transfer of socio-economic benefit from rich to poor. On the other hand, less leakage from lower strata means that the poor do not receive all the socio-economic benefits (Baker \& Adhikari, 2007).

The previous studies have used secondary data for measuring the socio-economic mobility of households in terms of paradigm shift from lower socio-economic strata to a higher one. This study proposes the most widely used socioeconomic status scale for urban and rural mobility patterns (Côté et al., 2021). The concept of mobility in the shade of intra-temporal households is the new one in the literature of Pakistan especially based on primary data. In this study, the concept of the leaky bucket (Okun, 2015) has been used to observe the consequences of mobility in terms of leakage and injection of house.

The present study attempts to measure the stratification and mobility pattern of Central Punjab based on intragenerational and intra-temporal household mobility. The main objective of this study is to analyze the role of mobility in raising the degree of socio-economic opportunity of life chances which helps leakage of households toward upper strata. Furthermore, it depicts the picture of socio-economic mobility of Central Punjab based on intra-generational and intratemporal household's mobility. It divides the heterogeneous population into homogeneous strata with the help of the socio-economic status index (SESI).

\section{Objectives}

- To analyze the role of mobility in raising the degree of socio-economic opportunity of life chances.

- To measure the picture of socio-economic mobility of central Punjab.

- To provide the best policy to the policymaker for economic growth.

\section{METHODOLOGY}

This study uses the prevalence rate to determine the sample size of three districts (Lahore, Sheikhupura, and Chiniot) of Central Punjab. Lahore, the biggest and developed city in Central Punjab, has the highest literacy rate, while Sheikhupura and Chiniot fall under the category of districts with middle and lower literacy rates. These districts have been selected based on the level of education, as it leads to occupation progress which has become the major source of mobility in Central Punjab. The sample size has been determined based on each district's population (see appendixes 1 for details).

The targeted respondents of the study are the head of households between the age of 45 and 65 , actively engaged in the labour market. Socio-economic status (SES) depends on the respondent's present occupation, income, and other factors at the interview, especially when the respondents are roughly over 50 years of age or close to retirement. The year 2000 is considered the base year to measure a household's socio-economic status, and 2017 is considered a final year to measure the current socio-economic status of households. The gap between the years 2000 and 2017 is over 15 years which is sufficient to measure the intra-generational and intra- temporal household's mobility.

For measuring the weights of socio-economic indicators, Principal Component Analysis (PCA) is regarded as the best summary empirical method. The study uses PCA for calculating Socio-economic Status Index (SESI) by assigning the weights to indicators. Then stratification process is conducted through the Socio-economic Status Index (SESI) of each indicator and then sum up the weighted variables to reach a final estimate of $\mathrm{j}$ households in a particular domain (Mpango, 2013). These weights show the relative importance of the variables included in the socio-economic index and bridging up the geographical importance in urban and rural perspectives. The socio-economic status score range has been divided into five strata categories using the inclusive method of class interval. The composite score of the households is categorized into five classes based on their total scores on the index (Tiwari and Kumar, 2005; Nayab, 2011).

$S E S I_{D 0 J}=\gamma_{e i} w_{e}+\gamma_{o i} w_{o}+\gamma_{i n i} w_{i}+\gamma_{e x i} w_{e x}+\gamma_{a i} w_{a}$
$S E S I_{D 1 J}=\gamma_{e i} w_{e}+\gamma_{o i} w_{o}+\gamma_{i n i} w_{i}+\gamma_{e x i} w_{e x}+\gamma_{a i} w_{a}$ 
$S E S I_{D 2 J}=\gamma_{e i} w_{e}+\gamma_{o i} w_{o}+\gamma_{i n i} w_{i}+\gamma_{e x i} w_{e x}+\gamma_{a i} w_{a}$

The classification of the SES group is presented in Table 1.

Table 1: Classification of SES Groups

\begin{tabular}{llll}
\hline Socio-economic stratification of Central Punjab & \multicolumn{2}{c}{ SES score of each domain } \\
\cline { 2 - 3 } & \multicolumn{1}{c}{$\boldsymbol{D}_{\boldsymbol{O}}$} & \multicolumn{1}{c}{$\boldsymbol{D}_{\mathbf{1}}$} & \multicolumn{1}{c}{$\boldsymbol{D}_{\mathbf{2}}$} \\
\hline Ruler/heavy privileged socio-economic strata & $\geq 20$ & $\geq 25$ & $\geq 27$ \\
\hline Privileged socio-economic strata & $16-19$ & $20-24$ & $22-26$ \\
\hline Survivors/active occupation socio-economic strata & $12-15$ & $15-19$ & $17-21$ \\
\hline Struggling/inactive occupation socio-economic strata & $8-11$ & $10-14$ & $12-16$ \\
\hline Creeper SE strata & $4-7$ & $5-9$ & $7-11$ \\
\hline
\end{tabular}

Source: Authors Calculation

The following logistic regression model has been used to analyse the relationship between the socio-economic factor and mobility in Central Punjab.

The Model:

$Y_{i j}=\beta_{0}+\beta_{1} X_{O C C}+\beta_{2} X_{E D U}+\beta_{3} X_{D E P}+\beta_{4} X_{E A R N E R}+\beta_{5} X_{M O V}+\mu_{i}$

The descriptions of the variables included in the model are presented in Table 2.

Table 2: Description of the Variables

\begin{tabular}{|c|c|}
\hline Variables & Description of Variable \\
\hline $\begin{array}{l}Y_{i j} \text {, Dependent variable calculated } \\
\text { through SES index. }\end{array}$ & $\begin{array}{l}\text { SES index-based household is; } \\
1=\text { if households transform from one socio-economic strata to another } \\
\text { during a } 15 \text {-year economic cycle. } \\
0=\text { otherwise. }\end{array}$ \\
\hline $\begin{array}{l}X_{O C C}, \text { Occupation improvement of } \\
\text { head of households }\end{array}$ & $\begin{array}{l}\text { There are three categories of occupation of the head of household; } \\
0=\text { non- improved from the base year, } \\
1=\text { Occupation progress from semi-skilled to clerical, } \\
2=\text { Occupation progress from semi-professional to professional. } \\
\text { This variable is used to study the association between occupation } \\
\text { progression of the head of household and upward mobility. }\end{array}$ \\
\hline$X_{E D U}$, Level of education & $\begin{array}{l}\text { The average score of education members of all households, } \\
\text { ' } 0 \text { ' if } X \leq 2.5 \text {, ' } 1 \text { ' if } X>2.5 \text {. } \\
\text { Education creates a sense of awareness about a better life, which increases } \\
\text { mobility. }\end{array}$ \\
\hline $\begin{array}{l}X_{D E P}, \text { number of dependent } \\
\text { members of the household }\end{array}$ & $\begin{array}{l}\text { Members less than } 18 \text { years and above } 60 \text { years of age are included in this } \\
\text { variable. } \\
\text { ' } 0 \text { ' if } X<2, \text { ' } 1 \text { ' if } X \geq 2 \text {. } \\
\text { This variable shows the negative relationship between the number of } \\
\text { dependent members of households and upward mobility. }\end{array}$ \\
\hline $\begin{array}{llll}X_{\text {EARNER }}, & \text { Number } & \text { of } & \text { Earning } \\
\text { member } & & & \end{array}$ & $\begin{array}{l}\text { The number of earning members among the total number of households, } \\
\text { ' } 0 \text { ' if } X<2 . \text {, ' } 1 \text { ' if } X \geq 2 \text {. } \\
\text { This variable measures the association between more earning hands and } \\
\text { upward mobility }\end{array}$ \\
\hline$X_{M O V}$, Movement within the country & $\begin{array}{l}\text { One }=\text { if households move toward other cities for betterment, } \\
\text { '0'otherwise. } \\
\text { This variable is used to study the association between inter-country } \\
\text { movement and upward mobility for better education, occupation, and } \\
\text { family development. }\end{array}$ \\
\hline
\end{tabular}

\section{RESULTS/FINDINGS/DISCUSSION}

Intra-generational leakage and injection analysis is presented in Table 3.

Table 3: Intra-generational leakages and injection analysis

\begin{tabular}{ll}
\hline $\begin{array}{l}\text { Socio-economic } \\
\text { stratification }\end{array}$ & Leakage and injection analysis of household \\
\hline Ruler strata & Injection transformation \\
\hline
\end{tabular}




\begin{tabular}{ll}
\hline $\begin{array}{l}\text { Privileged } \\
\text { Strata }\end{array}$ & Leakage < injection, size of strata increases due to more inject from survivors. \\
\hline $\begin{array}{l}\text { Survivors/ } \\
\text { Active }\end{array}$ & $\begin{array}{l}\text { Leakage }<\text { injection, size of strata increases due to less leakage and more injection from } \\
\text { struggling strata. This is the emerging middle class of our society. }\end{array}$ \\
\hline Struggling strata & $\begin{array}{l}\text { Leakage }>\text { injection, size of strata reduces due to more leakage and less injection from the } \\
\text { lower side, which is questionable for policymaker }\end{array}$ \\
\hline $\begin{array}{l}\text { Creeper } \\
\text { Strata }\end{array}$ & Leakage transformation, still heavy underprivileged occupied strata. \\
\hline
\end{tabular}

\section{Source: Author's calculation}

No remarkable changes have been noticed in society based on intra-generational mobility. The heads of the household may not have extraordinary potentials to replace their position in the hierarchy. There is the possibility that some of the heads of household were educated but were occupationally deprived. As a result, Central Punjab exhibits a low extent of intra-generational mobility as compared to intra-temporal mobility. In terms of intra-generational $\left(D_{0} \rightarrow D_{1}\right)$, one-step mobility has been observed in lower strata toward higher socio-economic strata. There exists a direct relationship between socio-economic opportunities and mobility in central Punjab. It is because the leakage of the households shows that struggling and survivor strata have the potential to improve their socio-economic status through the improvement in education and occupation progression and inject toward upper strata. The extent of mobility is low in intra-generational mobility because other invisible factors of the household bring positive change in society as upward transformation.

The intra-temporal leakage and injection analysis is presented in Table 4.

Table 4: Intra-temporal leakages and injection analysis

\begin{tabular}{ll}
\hline $\begin{array}{l}\text { Socio-economic } \\
\text { stratification }\end{array}$ & Leakage and injection analysis of household \\
\hline Ruler strata & Injection transformation \\
\hline $\begin{array}{l}\text { Privileged } \\
\text { Strata }\end{array}$ & $\begin{array}{l}\text { Leakage < injection, size of strata increases due to more injection from survivors as well } \\
\text { as struggling strata which show the trickle-down effect of society }\end{array}$ \\
\hline $\begin{array}{l}\text { Survivors/ } \\
\text { Active }\end{array}$ & $\begin{array}{l}\text { Leakage < injection, size of strata increases due to comparatively few leakages and more } \\
\text { injection from struggling strata. }\end{array}$ \\
\hline Struggling strata & $\begin{array}{l}\text { Leakage }>\text { injection, size of strata reduces due to more leakage and less injection from } \\
\text { the lower side, which is questionable for policymaker }\end{array}$ \\
\hline $\begin{array}{l}\text { Creeper } \\
\text { strata }\end{array}$ & Leakage transformation, still heavy underprivileged occupied strata. \\
\hline
\end{tabular}

\section{Source: Author's calculation}

In intra-temporal household mobility, more households are transformed toward upper strata, and two-step transformation has been observed in the survivor's strata (Silva \& Duarte, 2021). The households of survivor strata have been transformed up to privileged, and a few households have transformed toward ruler strata based on their education and occupation progress. The highly educated households show more mobility as they get jobs in the labour market compared to those who fail to attain a high level of education. The results of this study are in line with (Miliband 2003; Delorenzi et al., 2005). It is important to note that households with more education, occupation, and earning opportunities tend to rise. The size of privileged socio-economic strata dramatically increases due to more leakage of households from survivor and struggling strata. It indicates that households of Central Punjab can provide socioeconomic benefits to middle strata and show the sign of convergence because there are more chances of the distribution of socio-economic resources from rich to poor (Levesque et al., 2021). Central Punjab satisfies the notion of Okun (2015). The leakage transformation is visible from middle strata toward higher strata, which means transferring the socio-economic benefits from rich to the middle strata. The leakage and injection toward upper strata reveal equality and efficiency in the structure of society. The struggling and survivor strata appear as the most stimulated group, which show intra-generational or intra-temporal household transformation because households move from inactive/unskilled occupation toward skilled/active occupation categories.

The rate of mobility during fifteen years of the economic cycle in Central Punjab is presented in Table 5.

Table 5: Rate of Mobility During 15 Year Economic Cycle in Central Punjab

\begin{tabular}{llccc}
\hline & Urban analysis & \multicolumn{2}{l}{ Rural analysis } \\
\hline & \multicolumn{1}{c}{$D_{0} \rightarrow D_{1}$} & $D_{0} \rightarrow D_{2}$ & $D_{0} \rightarrow D_{1}$ & $D_{0} \rightarrow D_{2}$ \\
\hline Ruler strata & No leakage only inject transformation & No leakage only inject transformation \\
\hline Privileged SE strata & 0.22 & 0.44 & 0.17 & 0.34 \\
\hline Survivors/active occupation strata & 0.19 & 0.61 & 0.26 & 0.39 \\
\hline Struggling/inactive occupation & 0.17 & 0.40 & 0.19 & 0.38 \\
\hline
\end{tabular}




\begin{tabular}{lllll}
\hline Creeper SE strata & 0.18 & 0.33 & 0.09 & 0.21 \\
\hline
\end{tabular}

Source: Author's calculation

The results presented in Table 5 show that a significant change has been observed in the rate of mobility in intratemporal transformation compared to intra-generational mobility. The more leakage of households towards higher strata is observed due to other earning hands, which means next generation has to play its role in the change in society because $61 \%$ and $40 \%$ household decline in survivors and struggling SE Strata of Central Punjab and transform toward the higher ladder. In Central Punjab, the important aspect is that the size of its higher strata increases as it provides socioeconomic benefits to lower strata. The trickle-down effect is also realized as the size of higher strata increases with the fall in the size of lower strata. The structure of Central Punjab shows the stickiness between ruler and creeper socioeconomic strata, while the variability of mobility exists among the middle three strata. This indicates that the rich have become richer and the poor have become poorer. The analysis of socio-economic factors of Central Punjab and urban and rural regions of Central Punjab are presented in Table 6 and Table 7.

The results presented in Table 6 show that the education level of the household is positively associated with upward mobility. This indicates that educated households have more chances of upward mobility in 15 years economic cycle than uneducated. In Central Punjab, the educated households have 27.8 times more chances of transformation toward the upper strata. Furthermore, the coefficients of the household's education level are positive and statistically significant at a $1 \%$ level of significance for urban and rural regions of Central Punjab (2.7 and 2.6 respectively).

Table 6: The Analysis of Socio-economic Factors of Central Punjab

\begin{tabular}{llll}
\hline Variables & $\mathbf{e x p}_{\boldsymbol{\beta}}$ & $\mathbf{s l o p e}_{\boldsymbol{\beta}}$ & $\mathbf{p}$-values \\
\hline Household Education Level & 28.896 & 3.364 & .000 \\
\hline Number of Dependent Members & .186 & -1.684 & .001 \\
\hline Earning Members & 12.262 & 2.112 & .000 \\
\hline Geographical Movement & 8.409 & 2.129 & .000 \\
\hline Occupational Progression: From Semi-Skilled to clerical & 27.744 & 3.323 & .000 \\
\cline { 2 - 4 } Occupational Progression: From Semi-Professional to Professional & 33.206 & 3.503 & .000 \\
\hline Constant & $5.150(.000)$ & \\
\hline Negelkerkey R-Square & .53 & & \\
\hline The goodness of fit Test (x2) Hosmer-Lemeshow & $5.7(.67$ level of significance) \\
\hline
\end{tabular}

Source: Author's calculations

Table 7: Socio-economic Factors Analysis of Urban and Rural, Central Punjab

\begin{tabular}{|c|c|c|c|c|c|c|}
\hline \multirow[b]{2}{*}{ Variables } & \multicolumn{3}{|c|}{ Central Punjab (Urban) } & \multicolumn{3}{|c|}{ Central Punjab (Rural) } \\
\hline & $\exp _{\beta}$ & slope $_{\beta}$ & p-values & $\exp _{\beta}$ & slope $_{\beta}$ & $\begin{array}{l}\text { p- } \\
\text { values }\end{array}$ \\
\hline Household Education Level & 16.379 & 2.796 & .000 & 14.746 & 2.691 & .000 \\
\hline Number of Dependent Members & .230 & -1.469 & .059 & .308 & -1.177 & .042 \\
\hline Earning Members & 12.353 & 2.514 & .003 & 3.592 & 1.279 & .026 \\
\hline Geographical Movement & 11.983 & 2.484 & .003 & 8.913 & 2.188 & .000 \\
\hline $\begin{array}{l}\text { Occupational Progression: From Semi- } \\
\text { Skilled to clerical }\end{array}$ & 9.5 & 2.2 & .04 & 9.792 & 2.282 & 000 \\
\hline $\begin{array}{l}\text { Occupational Progression: From Semi- } \\
\text { Professional to Professional }\end{array}$ & 22.1 & 3.7 & .06 & 16.6 & 2.814 & 006 \\
\hline Constant & $-4.6(.00)$ & & & $-4.8(000$ & & \\
\hline Negelkerkey R-Square & .53 & & & .66 & & \\
\hline $\begin{array}{l}\text { The goodness of fit Test (x2) Hosmer- } \\
\text { Lemeshow }\end{array}$ & $10.0(.26$ & of siq & ance) & 7.2.40 1 & el of sign & icance) \\
\hline
\end{tabular}

Source: Author's calculations

It reveals that the average high education level promotes chances of mobility in both urban and rural regions. These results support the arguments made by Connor \& Dewson (2001), Forsyth and Furlong (2003); Qamar (2014); Masooma (2013).

The impact of a more number of dependent members is inversely associated with upward mobility of households, and the odds ratio of 0.18 shows that $(1-0.18=0.82)$ households have $82 \%$ low chances of upward mobility. The chances of 
upward mobility increase as households have 77\% (1-0.23)*100 and 70\% (1-0.30)*100 fewer dependent members in urban and rural regions. Our results are consistent with Freud (2007).

The participation ratio in the labour market appears directly related to the upward mobility of households. The results reveal that more earning members in a family have 11.2 times more chances of upward mobility. The coefficients of earning members are positive and statistically significant at a $1 \%$ level of significance in both urban and rural regions of Central Punjab. It indicates that households with more earning members have 12.3 and 3.5 times more chances of upward mobility in urban and rural Central Punjab, respectively (Bechlioulis \& Brissimis, 2021).

The results show that the households with geographical movement toward developed areas have 7.4 times more chances of upward mobility compared to others. This indicates that households are more likely to enjoy the benefits of mobility due to inter-country movement with the odd values of 10.9 and 7.9 in urban and rural regions of Central Punjab, respectively. These results are consistent with Gibbons and Silva (2006), Delorenzi (2006), Murphy (2006).

Occupation is considered an intervening variable that links income to education and raises the socio-economic status of households. The chances of upward mobility of households are 32.1 times more if the heads of household progress themselves in the labour market toward semi-professional to professional. Comparatively, the occupation progress of household from semi-skilled to clerical has only 26.7 times more chances. The more chances of occupation transformation/progression from semi-professional to professional are 21.1 and 15.6 times in urban and rural Central Punjab. Furthermore, households are more likely to be transformed 8.5 and 8.7 times in urban and rural Central Punjab, respectively, through occupation progression from semi-skilled to clerical from base year relative to final year.

\section{CONCLUSION}

The descriptive analysis of mobility shows the size of strata after leakage or injection. The study finds that basic needs like food, clothes, and shelter are important for creeper socio-economic strata. As a result, households in this strata face a low rate of mobility. The basic needs of struggling socio-economic strata are physiological needs, like food, clothes, shelter, safe residence, education, and respectable job. As a result, this stratum experiences a satisfactory rate of mobility in Central Punjab. The major characteristics of middle socio-economic strata include the desire for higher education and achievements of the high rate of occupation mobility. This stratum is considered the backbone of an economy as it observes an extraordinary rate of socio-economic mobility. The size of both lower strata decreases while the size of survivors, privileged, and ruler socio-economic strata increases. The amount of increase or decrease in strata depends on each strata denominator number of households $D_{0}$. The size of privileged strata increases more due to the injection of more households from survivor strata. This indicates the progress path of the society as higher strata size increases due to a decrease in the size of lower strata.

The valuable part of Central Punjab is that its upper two socio-economic strata are integrated. Both strata consist of bourgeois, businessman, landlord, and executive class of the society that becomes the ruler and have commanding authority for bottom strata. The logistic regression analysis of Central Punjab shows that opportunities of education and occupation serve as a bridge to increase household income level and socio-economic status. Educational attainment appears as a strong predictor of the socio-economic transformation of households, which means an improvement in education increases the occupation level, which further enhances the income level of households. The developed occupation market also plays an intermediate role to convert the improved education level into income level.

\section{LIMITATIONS AND STUDY FORWARD}

This study presents the leakage and injection of different strata and their impact on the income level of households. But the study does not throw light on the distribution of income among households. Furthermore, it ignores the impact of changes in income on the consumption behaviour of households. Keeping in view the limitations mentioned above, this research work can be extended by analyzing the impact of households' income on their consumption behaviour. Furthermore, the relationship between socio-economic mobility and the distribution of income can be analyzed in Central Punjab.

\section{IMPLICATION OF STYDY}

The major contribution of this study is to provide guidelines to the policymakers in developing appropriate policies for deprived areas of Central Punjab based on the analysis of leakage and injection of households. Therefore, this study may bridge the research gap intensively with the help of two different domains of the same households (intra-generational and intra-temporal mobility).

\section{ACKNOWLEDGEMENT}

Thanks to all of my colleagues who have been so encouraging in the research process. I want to express my heartfelt gratitude to my family and friends for their continuous support in conducting this research. 


\section{AUTHORS CONTRIBUTION}

Samra Khalid and Nabila Asghar conceptualized the presented idea. Hafeez ur Rehman conceptualised the theoretical framework and performed the calculations. Nabila Asghar verified the analytical methods. For complete empirical analysis, all authors contributed to the final manuscript.

\section{REFERENCES}

1. Baker, J., \& Adhikari, P . (2007). Socio-economic indexes for individuals and families. Abs methodology advisory committee, Analytical Services Branch.

2. Bechlioulis, A. P., \& Brissimis, S. N. (2021). Identifying key aspects of household behavior in a representative agent framework. Economic Modelling, 97, 105-117. https://doi.org/10.1016/j.econmod.2021.01.017

3. Cepeliauskaite, G., Keppner, B., Simkute, Z., Stasiskiene, Z., Leuser, L., Kalnina, I., ... \& Muiste, M. (2021). Smart-Mobility Services for Climate Mitigation in Urban Areas: Case Studies of Baltic Countries and Germany. Sustainability, 13(8), 4127. https://doi.org/10.3390/su13084127

4. Connor, H., \& Dewson, S. (2001). Social class and higher education issues affecting decisions on participation by lower social class groups(DFEE Research Report RR267). https://dera.ioe.ac.uk/4621/1/RR267.pdf

5. Corak, M. (2013). Income inequality, equality of opportunity, and intergenerational mobility, (Discussion Paper No. 7520). http://ftp.iza.org/dp7520.pdf

6. Côté, S., Stellar, J. E., Willer, R., Forbes, R. C., Martin, S. R., \& Bianchi, E. C. (2021). The psychology of entrenched privilege: High socioeconomic status individuals from affluent backgrounds are uniquely high in entitlement. Personality and Social Psychology Bulletin,47(1), 70-88. https://doi.org/10.1177/01461 $\underline{67220916633}$

7. Delorenzi, S. (2006). Neighborhood, ethnicity and social mobility. Institute for Public Policy Research, vol-1, $1-11$.

8. Delorenzi, S., Reed, J., \& Robinson, P. (2005). Maintaining momentum: promoting social mobility and life chances from early years to adulthood. Institute for Public Policy Research.

9. Dean, H., McNeil, V., \& Melrose, M. (2003). 'Ready to Work? Understanding the experiences of people with multiple problems and needs'. Benefts, 11(36), 19-25.

10. Forsyth, A,. \& Furlong, A. (2003). Access to higher education and disadvantage, young people. British Educational Research Journal, 29 (2), 205-225. https://doi.org/10.1080/0141192032000060948

11. Freud, D. (2007). Reducing dependency, increasing opportunity: options for the future of welfare to work: An independent report to the Department for Work and Pensions. Department for Work and Pensions.

12. Gaur, K. L. (2013 ). Socio-Economic status measurement scale: Thirst area with changing concept for socioeconomic status. International Journal of Innovative Reserch and Development, 2(9), 139-145.

13. Gibbons, S., \& Silva, O. (2006). Faith Primary Schools: Better Schools or Better Pupils? Journal of Labor Economics, 29(3), 589-635. https://doi.org/10.1086/659344

14. Grusky, D. B. (2001). Social stratification: Class, race, and gender in sociological perspective. 2nd ed. Boulder, Colo, Westview Press.

15. Green, N. E. (1956). Scale analysis of urban structures: A study of Birmingham, Alabama. American Sociological Review, 21(1), 8-13. https://doi.org/10.2307/2089333

16. Goldthorpe, J. H. (2016). Social class mobility in modern Britain, changing structure, constant process. Journal of the British Academy, 4, 89-111. https://doi.org/10.5871/jba/004.089

17. Jantti, M., \& Jenkins, S. P. (2013). Income Mobility (Discussion Paper No. 7730). https://www.econstor.eu/b itstream/10419/89975/1/dp7730.pdf

18. Jimoh, M. Y., Bikam, P., \& Chikoore, H. (2021). The Influence of Socioeconomic Factors on Households' Vulnerability to Climate Change in Semiarid Towns of Mopani, South Africa. Climate, 9(1), 13. https://doi.org/10.3390/cli9010013

19. Khalid, S., \& Asghar, N. (2018). Measuring Socio economic Stratification and Mobility Pattern: Case study of Intra-Generational and Intra-Temporal Household Mobility of southern Punjab, Pakistan. Review of Economics and Development Studies, 4 (2), 321-329. https://doi.org/10.26710/reads.v4i2.417

20. Khalid, S., \& Asghar, N. (2019). An Analysis of Socio economic Stratification, Intra-Temporal and IntraGenerational Household Mobility in Central Punjab, Pakistan. Global Social Sciences Review (GSSR), 4(11), 112. https://doi.org/10.31703/gssr.2019(IV-II).01

21. Levesque, A. R., MacDonald, S., Berg, S. A., \& Reka, R. (2021). Assessing the Impact of Changes in Household Socioeconomic Status on the Health of Children and Adolescents: A Systematic Review. Adolescent research review, 1-33. https://doi.org/10.1007/s40894-021-00151-8

22. Machin, S. (2004). Educational inequality: The widening socio-economic gap. Fiscal Studies, 25(2), 107-128. https://doi.org/10.1111/j.1475-5890.2004.tb00099.x

23. Miliband, D. (2003). Opportunity for all: targeting disadvantage through personalized learning', New Economy, 224-229. https://doi.org/10.1046/j.1468-0041.2003.00322.x 
24. Mpango, P. (2013). Socio-Economic transformation for poverty reduction: Eight key messages for unlocking Tanzania's Potential. (REPOA Brief Number 37). http://www.repoa.or.tz/wp-content/uploads/2020/07/REPO A_BRIEF 37.pdf

25. Murphy, J. T. (2006). Representing the economic geographies of "others" reconsidering the global south. Journal of Geography in Higher Education, 30(3), 439-448. https://doi.org/10.1080/03098260600927369

26. Masooma, H. (2013). Education in Pakistan's Punjab: Outcomes and interventions. Lahore Journal of Economics, 18. https://doi.org/10.35536/lje.2013.v18.isp.a2

27. Nayab, D. (2011). Estimating the middle class in Pakistan. The Pakistan Development Review, 50(1), 1-28. https://doi.org/10.30541/v50i1pp.1-28

28. Okun, A. M. (2015). Equality and efficiency: The Big Tradeoff. The Brookings Institution.

29. Qamar, A. H. (2014). Challenges associated with primary education in rural Punjab, Pakistan: primary education in rural Punjab, Pakistan. LAP LAMBERT Academic Publishing.

30. Ritchie, H., Casebourne, J., \& Rick, J. (2005). Understanding workless people and communities: A literature review ( DWP Research Report No. 255).

31. Salata, A., \& Scalon, C. (2020). Socioeconomic mobility, Expectations and attitudes towards inequality in Brazil. Sociol. Antropol, 10(2). https://doi.org/10.1590/2238-38752020v10213

32. Silva, N. B. D., \& Duarte, A. M. P. (2021). Essential and non-essential goods: a dynamic stochastic general equilibrium modeling of the infectious disease coronavirus (COVID-19) outbreak. New Challenges for the Eurozone Governance: Joint Solutions for Common Threats? 171-185. https://doi.org/10.1007/978-3-030$\underline{62372-2 \quad 9}$

33. Tiwari, S., \& Kumar, A. (2005). A scale to measure socio-economic status in urban \& rural communities in India." Indian J . The Indian Journal of Medical Research, 122(4), 288-290.

34. Weissberger, G. H., Núñez, R. A., Tureson, K., Gold, A., \& Thames, A. D. (2021). Socioeconomic Mobility and Psychological and Cognitive Functioning in a Diverse Sample of Adults With and Without HIV. Psychosomatic medicine, 83(3), 218-227. https://doi.org/10.1097/PSY.0000000000000929

35. Wuyts, M., \& Kilama, B. (2014). Economic transformation in Tanzania vicious or virtuous circle (Background Paper No. 2 ). https://www.thdr.or.tz/docs/THDR-DP-56.pdf

Appendix 1: Sample size of Central Punjab

\begin{tabular}{lcl}
\hline Central Punjab P $=60 \%, \boldsymbol{Z}_{\alpha}=95 \%(1.96)$, Central Punjab sample $=370$ \\
\hline District sample & Urban sample & Rural sample \\
\hline Lahore, $\mathbf{n}=\mathbf{2 4 0}$ & 89 & 151 \\
\hline Sheikhupura, $\mathbf{n}=\mathbf{8 0}$ & 30 & 50 \\
\hline Chiniot, $\mathbf{n}=\mathbf{5 0}$ & 18 & 32 \\
\hline
\end{tabular}

Appendix 2: Analysis criteria of Intra-generational and Intra-temporal household mobility

\begin{tabular}{lll}
\hline Analysis criteria $\mathbf{D}_{\mathbf{0}}$ & \multicolumn{1}{c}{ Analysis criteria $\boldsymbol{D}_{\mathbf{1}}$} & \multicolumn{1}{c}{ Analysis criteria $\mathbf{D}_{\mathbf{2}}$} \\
\hline $\begin{array}{l}\text { Education (head of household } \\
\text { education score) }\end{array}$ & $\begin{array}{l}\text { Education (head of household } \\
\text { education score, either improved or } \\
\text { not by base year) }\end{array}$ & $\begin{array}{l}\text { Education (Average score of education } \\
\text { member of all household) }\end{array}$ \\
\hline $\begin{array}{l}\text { Occupation (head of } \\
\text { household occupation score) }\end{array}$ & $\begin{array}{l}\text { Occupation (head of household } \\
\text { occupation score, either improved or } \\
\text { not by base year) }\end{array}$ & $\begin{array}{l}\text { Occupation (Average score of all earners } \\
\text { of household), }\end{array}$ \\
\hline Base year income & Final year Adjusted Income. & Total Household income \\
\hline Expenditure pattern & Household expenditure pattern & Expenditure pattern \\
\hline Asset & Asset & Assets \\
\hline
\end{tabular}

